\title{
Leaching Kinetics of Secondary Zinc Oxide in a $\mathrm{NH}_{3}-\mathrm{NH}_{4} \mathrm{HCO}_{3}-\mathrm{H}_{2} \mathrm{O}$ System
}

\author{
Hui Li, Linfei Zhao, Le Wang, Jinglong Liang *, Hongyan Yan and Jinrui Liu
}

Citation: Li, H.; Zhao, L.; Wang, L.; Liang, J.; Yan, H.; Liu, J. Leaching Kinetics of Secondary Zinc Oxide in a $\mathrm{NH}_{3}-\mathrm{NH}_{4} \mathrm{HCO}_{3}-\mathrm{H}_{2} \mathrm{O}$ System. Crystals 2021, 11, 496. https:// doi.org/10.3390/cryst11050496

Academic Editors: Jie Dang, Jichao Li, Xuewei Lv, Shuang Yuan and Katarzyna Leszczyńska-Sejda

Received: 12 April 2021

Accepted: 27 April 2021

Published: 30 April 2021

Publisher's Note: MDPI stays neutral with regard to jurisdictional claims in published maps and institutional affiliations.

Copyright: (c) 2021 by the authors. Licensee MDPI, Basel, Switzerland. This article is an open access article distributed under the terms and conditions of the Creative Commons Attribution (CC BY) license (https:// creativecommons.org/licenses/by/ $4.0 /)$.
College of Metallurgy and Energy, North China University of Science and Technology, Tangshan 063210, China; lh@ncst.edu.cn (H.L.); 18331503112@163.com (L.Z.); wangl@ncst.edu.cn (L.W.); yanhy@ncst.edu.cn (H.Y.); liujr1890@126.com (J.L.)

* Correspondence: lj1@ncst.edu.cn
Abstract: Secondary zinc oxide (SZO), which comes from the zinc industry, is an important secondary resource of zinc and other valuable metals. In this study, the production feasibility and rationality of a cleaner zinc recovery process using SZO and a hydrometallurgical method were described. Zinc extraction is promoted by the addition of ammonium bicarbonate to a $\mathrm{NH}_{3}-\mathrm{H}_{2} \mathrm{O}$ system, and the maximum recovery of zinc could be close to $80 \%$ at the optimum leaching conditions of a stirring rate of $400 \mathrm{rpm}$, an ammonia/ammonium ratio of 7:3, a total ammonia concentration of $4 \mathrm{~mol} / \mathrm{L}$, and a liquid/solid ratio of $7 \mathrm{~mL} / \mathrm{g}$ for $30 \mathrm{~min}$ at $35^{\circ} \mathrm{C}$. The kinetics of leaching were modeled using the shrinking core model of constant-size particles, and the rate-controlling step was determined to be the diffusion through the product layer. The apparent activation energy of the reaction was estimated to be $11.04 \mathrm{KJ} \cdot \mathrm{mol}^{-1}$, while the order of reaction with respect to total ammonia concentration was 1.53 and the liquid/solid ratio was 2.26. The analysis results of the initial residue and the leached residue indicated that lead was transferred from $\mathrm{PbCl}_{2}$ to $\mathrm{PbCO}_{3}$ and that $\mathrm{ZnFe}_{2} \mathrm{O}_{4}$ was not leached in the $\mathrm{NH}_{3}-\mathrm{NH}_{4} \mathrm{HCO}_{3}-\mathrm{H}_{2} \mathrm{O}$ system.

Keywords: zinc recovery; ammonia leaching; secondary zinc oxide; leaching kinetic; shrinking core model

\section{Introduction}

Zinc has excellent recycling performance, and the utilization of secondary zinc resources has attracted more and more attention. The proportion of secondary zinc resources as raw materials for industrial production is increasing after years of research. SZO is a kind of secondary zinc resource. A large amount of secondary zinc resources are produced in industrial production every year, a large part of which is SZO. If secondary zinc resources are to be recycled, it is necessary to carry out research on the recycling of SZO. SZO is rich in valuable metal elements but also contains toxic elements such as lead, cadmium, and arsenic. Humans and animals would be poisoned, and the ecological environment would be affected by such elements, so they should be recycled by scientific means [1,2]. At the same time, the recovery of zinc in SZO can bring huge economic benefits [3]. Therefore, the development of new technologies to produce zinc from SZO has become an important research topic in recent years.

Because of the complex composition of SZO, it is difficult to recover, and unreasonable treatment methods will cause a waste of resources and even environmental pollution [4]. In industry, the hydrometallurgical method is generally used to recover zinc from SZO. Because the composition and content of SZO vary greatly in different production areas, the selection of SZO recovery process needs to be adjusted according to different raw materials. The treatment methods of SZO are mainly divided into the acid leaching method [5-8], the alkaline leaching method $[9,10]$ and the ammonia leaching method [11-15]. The advantage of the acid leaching method for leaching secondary zinc oxide is that the zinc extraction efficiency is good, but the leaching selectivity of this method is poor, and impurities such 
as manganese, aluminum, and arsenic are also leached, which increase the burden of the impurity removal process. Meanwhile, the arsenic and aluminum impurities are more difficult to remove completely. As a result, the quality of the obtained product is reduced, which limits the scope of use of the product $[5,16]$. The alkaline leaching method has good leaching selectivity but requires the use of a high concentration of alkali, and it has an unsatisfactory zinc extraction efficiency $[10,17]$. The ammonia leaching method has strong leaching selectivity; the impurity types and impurity content in the leaching solution are obviously reduced; and the subsequent impurity removal steps become simple. Many researchers have extracted zinc from secondary zinc resources with the ammonia leaching method and analyzed the leaching kinetics, established the kinetic models, and calculated the activation energy [18-20]. In addition, it has been found that the addition of ammonium ions can promote the extraction efficiency of zinc [21].

In this study, a zinc production process with the $\mathrm{NH}_{3}-\mathrm{NH}_{4} \mathrm{HCO}_{3}-\mathrm{H}_{2} \mathrm{O}$ system as the leaching agent was adopted, and the influence of various parameters on the kinetics of zinc extraction was analyzed. The kinetic data was modeled with the popular shrinking core model, which accounts for chemical reaction and product layer diffusion control. In addition, the order of the reaction was estimated using a semi-empirical equation for the diffusion-controlled process.

\section{Materials and Methods}

\subsection{Experiment Material}

The SZO was supplied by a zinc plant in Hebei, China. It was produced as flue ash during the high temperature treatment of metallurgical slag in rotary kilns. In order to determine the chemical composition of the main elements of $\mathrm{SZO}$, the quantitative analysis was performed by means of X-ray fluorescence spectroscopy (XRF; Rigaku-X, Nippon Science Co., Ltd., Japan). Table 1 showed that the main elements of $\mathrm{SZO}$ were $\mathrm{Zn}, \mathrm{Pb}, \mathrm{Cl}$, $\mathrm{Fe}, \mathrm{K}, \mathrm{S}$, and $\mathrm{O}$, among others.

Table 1. The main composition of SZO.

\begin{tabular}{ccccccccc}
\hline Element & $\mathbf{Z n}$ & $\mathbf{P b}$ & $\mathbf{C l}$ & $\mathbf{F e}$ & $\mathbf{K}$ & $\mathrm{S}$ & $\mathbf{O}$ & Others \\
\hline $\begin{array}{c}\text { Content } \\
(\%)\end{array}$ & 54.90 & 9.83 & 5.54 & 3.23 & 2.07 & 1.83 & 19.9 & 2.7 \\
\hline
\end{tabular}

The mineralogical composition of SZO was determined by X-ray diffraction (XRD; D/MAX2500PC, Nippon Science Co., Ltd., Japan). The XRD pattern in Figure 1 showed that $\mathrm{SZO}$ consists of $\mathrm{ZnO}, \mathrm{PbCl}_{2}, \mathrm{ZnFe}_{2} \mathrm{O}_{4}, \mathrm{Fe}_{3} \mathrm{O}_{4}, \mathrm{~K}_{2} \mathrm{~S}$, and FeS. It was basically consistent with the data in Table 1.

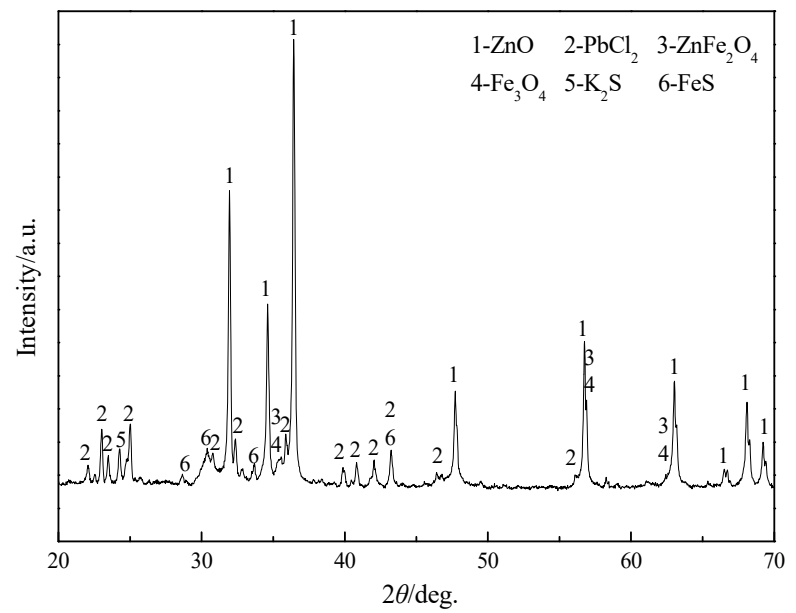

Figure 1. XRD pattern of SZO. 
The particle size and distribution of SZO were measured by laser particle size analysis (D/MAX2500PC, Microtrac Inc., USA). Figure 2 showed that the particle size was between $0.2-77 \mu \mathrm{m}$, and more than $90 \%$ of its mass was characterized by a grain diameter smaller than $35 \mu \mathrm{m}$. Meanwhile, $50 \%$ of the particles were smaller than $10 \mu \mathrm{m}$.

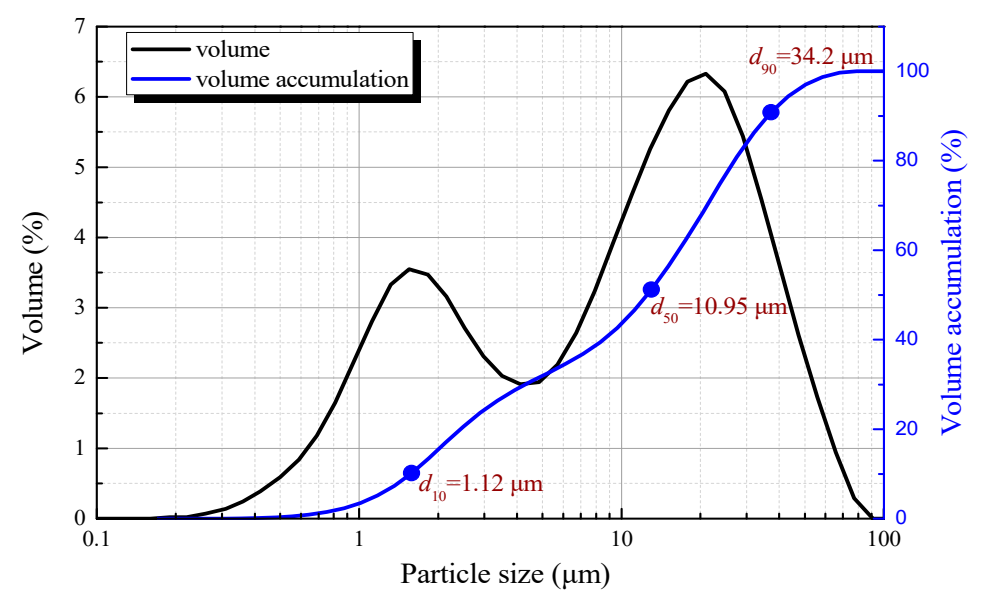

Figure 2. Laser particle size analysis of SZO.

\subsection{Experiment Methods}

The purpose of the work was to analyze the possibilities to apply the selected ammonium compounds for leaching the zinc that comes from the rotary kiln dust and to establish the kinetic model of the leaching process. $\mathrm{NH}_{4} \mathrm{HCO}_{3}$ and $\mathrm{NH}_{3} \cdot \mathrm{H}_{2} \mathrm{O}$ were determined as the solvent for this purpose. To determine the opportunity of the leaching process's occurrence and the transfer of zinc into solution in the form of ions, a Pourbaix diagram was used to analyze experimental parameters and to simplify the experimental process. Figure 3a presents a Pourbaix diagram for the $\mathrm{Zn}-\mathrm{C}-\mathrm{N}-\mathrm{H}_{2} \mathrm{O}$ system at a temperature of $25^{\circ} \mathrm{C}$, an $\mathrm{NH}_{4} \mathrm{HCO}_{3}$ concentration of $1 \mathrm{~mol} / \mathrm{L}$, a NH $\mathrm{NH}_{3} \cdot \mathrm{H}_{2} \mathrm{O}$ concentration of $3 \mathrm{~mol} / \mathrm{L}$, and a zinc concentration in the solution of $0.08 \mathrm{~mol} / \mathrm{L}$. The occurrence of zinc in the form of $\left(\mathrm{Zn}\left(\mathrm{NH}_{3}\right)_{4}\right)^{2+}$ when $\mathrm{pH}>7.3$ was anticipated in the Pourbaix diagram. Figure $3 \mathrm{~b}$ showed that the $\mathrm{pH}$ value of the $\mathrm{NH}_{3}-\mathrm{NH}_{4} \mathrm{HCO}_{3}-\mathrm{H}_{2} \mathrm{O}$ system was between 10.44-11.5, so it was possible to extract zinc with the ammonium compounds of $\mathrm{NH}_{4} \mathrm{HCO}_{3}$ and $\mathrm{NH}_{3} \cdot \mathrm{H}_{2} \mathrm{O}$.

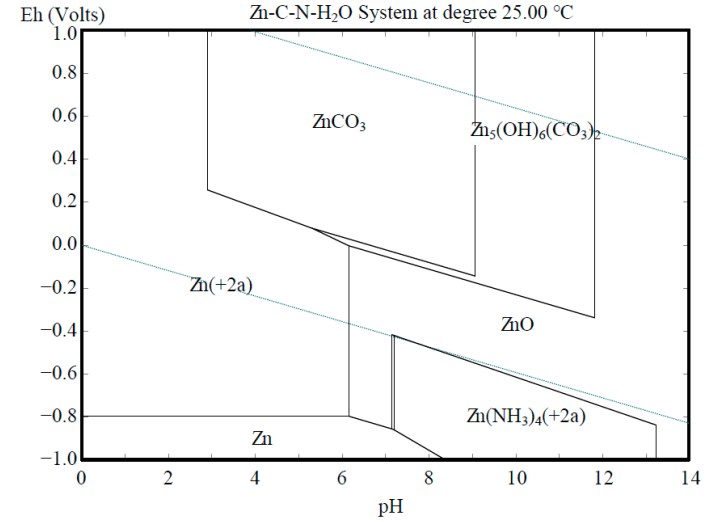

(a)

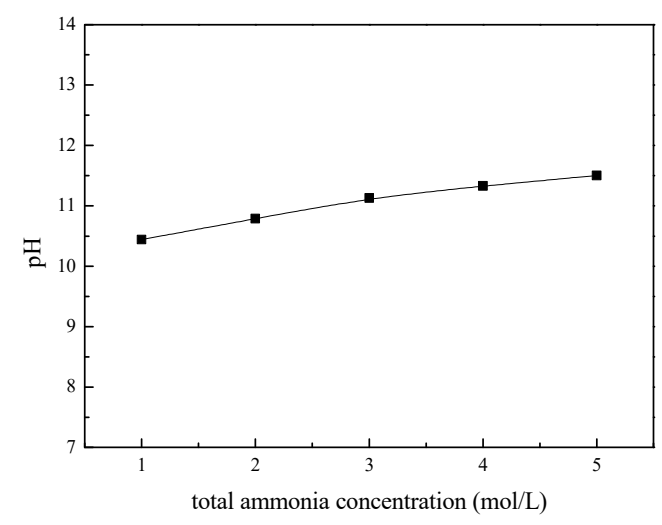

(b)

Figure 3. (a) Pourbaix diagram of the $\mathrm{Zn}-\mathrm{C}-\mathrm{N}-\mathrm{H}_{2} \mathrm{O}$ system $\left(25^{\circ} \mathrm{C}, 0.08 \mathrm{~mol} / \mathrm{L} \mathrm{Zn}, 1 \mathrm{~mol} / \mathrm{L} \mathrm{NH}_{4} \mathrm{HCO}_{3}, 3 \mathrm{~mol} / \mathrm{L} \mathrm{NH} 3 \cdot \mathrm{H}_{2} \mathrm{O}\right)$; (b) $\mathrm{pH}$ values of the $\mathrm{NH}_{3}-\mathrm{NH}_{4} \mathrm{HCO}_{3}-\mathrm{H}_{2} \mathrm{O}$ system (the ammonia/ammonium ratio was 3:1). 
In $\mathrm{NH}_{3}-\mathrm{NH}_{4} \mathrm{HCO}_{3}-\mathrm{H}_{2} \mathrm{O}$ system solutions, the dissolved zinc oxide can combine with ammonium ions and ammonia to form soluble $\left(\mathrm{Zn}\left(\mathrm{NH}_{3}\right)_{i}\right)^{2+}$ complexes, as shown in Equations (1) and (2).

$$
\begin{gathered}
\mathrm{ZnO}+i \mathrm{NH}_{4}^{+}=\left(\mathrm{Zn}\left(\mathrm{NH}_{3}\right)_{i}\right)^{2+}+\mathrm{H}_{2} \mathrm{O}+(i-2) \mathrm{H}^{+} \\
\mathrm{ZnO}+i \mathrm{NH}_{3}+\mathrm{H}_{2} \mathrm{O}=\left(\mathrm{Zn}\left(\mathrm{NH}_{3}\right)_{i}\right)^{2+}+2 \mathrm{OH}^{-}
\end{gathered}
$$

To further determine the distribution of zinc complexes in the solution, according to the chemical equation and stability constants of the zinc complexes, the calculation software was used to draw a diagram of the relationship between the distribution of zinc-ammonia complexes and $\lg \left[\mathrm{NH}_{3}\right]$ at a temperature of $298 \mathrm{~K}$. Figure 4 shows that several complexes coexisted in the solution at low ammonia concentrations. The coordination reaction could not be completed quantitatively according to a certain measurement relationship. With the increase in $\lg \left[\mathrm{NH}_{3}\right]$, zinc and ammonia gradually formed $\left(\mathrm{Zn}\left(\mathrm{NH}_{3}\right)\right)^{2+},\left(\mathrm{Zn}\left(\mathrm{NH}_{3}\right)_{2}\right)^{2+}$, $\left(\mathrm{Zn}\left(\mathrm{NH}_{3}\right)_{3}\right)^{2}$, and $\left(\mathrm{Zn}\left(\mathrm{NH}_{3}\right)_{4}\right)^{2+}$ complexes, and the dominant form gradually changed from $\mathrm{Zn}^{2+}$ to $\left(\mathrm{Zn}\left(\mathrm{NH}_{3}\right)_{4}\right)^{2+}$. When the total ammonia concentration was close to $1 \mathrm{~mol} / \mathrm{L}$, $\left(\mathrm{Zn}\left(\mathrm{NH}_{3}\right)_{4}\right)^{2+}$ was the main type, with more than $99.99 \%$ of the zinc in the solution in the form of $\left(\mathrm{Zn}\left(\mathrm{NH}_{3}\right)_{4}\right)^{2+}$, and other forms could be ignored.

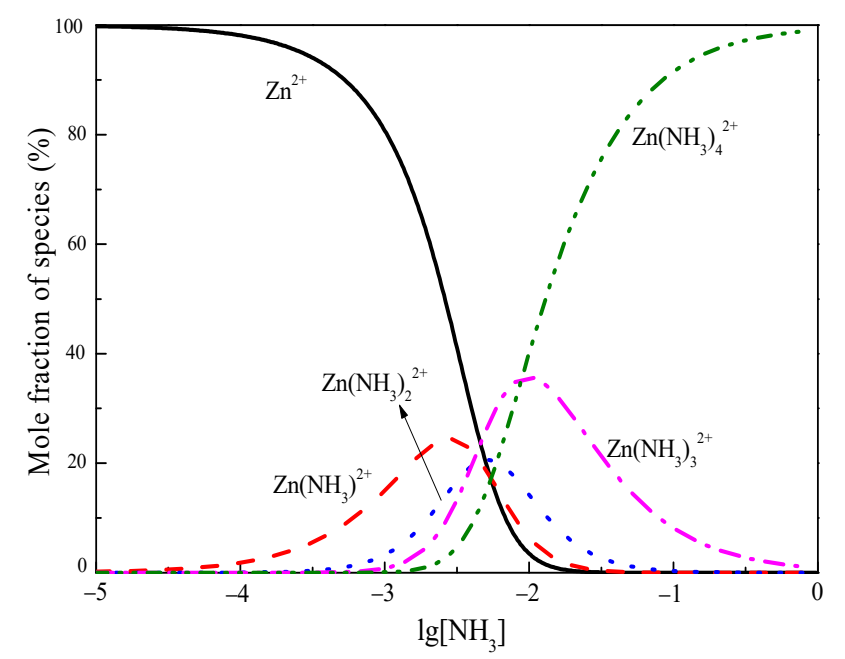

Figure 4. The relationship between the distribution of zinc-ammonia complexes and $\lg \left[\mathrm{NH}_{3}\right]$.

Solid-fluid heterogeneous reactions are common in chemical and hydrometallurgical processes. To determine the kinetic parameters and the rate-controlling step of the zinc leaching process, the popular shrinking core model was utilized. The shrinking core model was proposed by Levenspiel in 1972 when the gasp-solid reaction was studied [22]. It was mainly divided into two categories: the shrinking core model with constant particle size and the shrinking core model with reduced particle size [23]. The schematic diagram of the evolution of the leaching process is shown in Figure 5, and the kinetic equation of leaching is summarized in Table 2: 


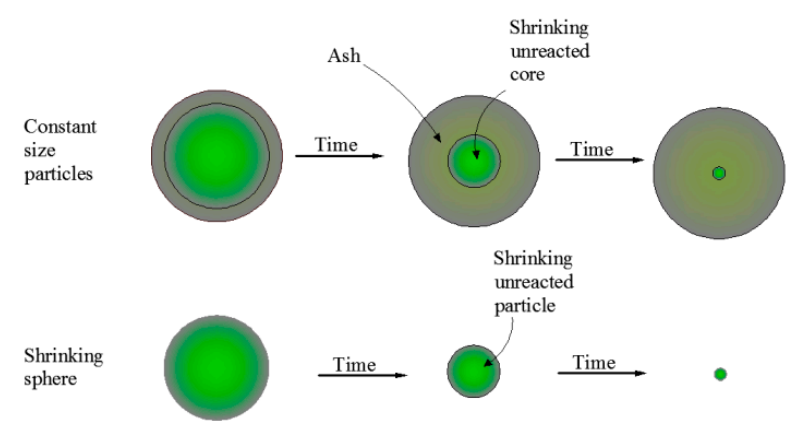

Figure 5. Schematic diagram of shrinking core models.

Table 2. Classification of kinetic models.

\begin{tabular}{cccc}
\hline Model & Type & Equation & Notation \\
\hline $\begin{array}{c}\text { Shrinking core models of } \\
\text { constant-size particles }\end{array}$ & $\begin{array}{c}\text { Product layer } \\
\text { diffusion controls } \\
\text { Chemical reaction } \\
\text { controls } \\
\text { Film diffusion } \\
\text { controls }\end{array}$ & $k_{d} t=1-(1-\alpha)^{2 / 3}$ & Equation (3) \\
\hline $\begin{array}{c}\text { Shrinking core models of } \\
\text { small shrinking spherical } \\
\text { particles }\end{array}$ & $\begin{array}{c}\text { Chemical reaction } \\
\text { controls } \\
\text { Product layer } \\
\text { diffusion controls }\end{array}$ & $k_{d} t=1-(1-\alpha)^{1 / 3}$ & Equation (4) \\
\hline
\end{tabular}

where $\alpha$ is the zinc extraction efficiency, $k_{d}$ is the kinetic parameter for control, and $t$ is the reaction time (min). The plot of the right side of Equations (3)-(7) versus time $(t)$ was expected to be linear to identify the appropriate controlling mechanism. The slope of the line is the rate constant $k_{d}$, while the temperature dependence of the reaction rate constant can be calculated using the Arrhenius equation [21]:

$$
k_{d}=A \exp \left(\frac{-E_{a}}{\mathrm{RT}}\right)
$$

where $A$ is the frequency factor, $E_{a}$ is the activation energy of the reaction, $\mathrm{R}$ is the universal gas constant, and $T$ is the absolute temperature.

Based on the above analysis, the effects of variable stirring speeds (150-400 rpm), the ammonia/ammonium ratio (1:0-0:1), the leaching temperature $\left(5-70{ }^{\circ} \mathrm{C}\right)$, the total ammonia concentration (1-5 mol/L), the liquid/solid ratio $(6-8 \mathrm{~mL} / \mathrm{g})$, and the leaching time (0-30 $\mathrm{min})$ on zinc extraction were assessed.

The leaching experiment was carried out in a three-necked flask immersed in an electric thermostatic water bath. A thermometer was used to determine the constant temperature. The process was assisted by a stirring paddle. Samples of the dust with a mass of $10 \mathrm{~g}$ were leached in a three-necked flask with solutions of $\mathrm{NH}_{4} \mathrm{HCO}_{3}$ and $\mathrm{NH}_{4} \mathrm{OH}$ of an appropriate amount and concentrations corresponding to the assumed mass ratio of liquid to the solid phase. After a specified leaching time, the filtrate and the filter residue were separated using a vacuum suction filter flask, and the residue was washed three times with distilled water. The filter residue was dried and weighed. The EDTA titration method was used to determine the content of zinc in the filtrate, and the average value of three measurements was taken. The formula for calculating the zinc extraction is given by Equation (9):

$$
\text { Extraction }(\%)=\frac{w_{s}}{w_{T}} \times 100 \%
$$


where $w_{S}$ is the weight of zinc in the leaching solution, and $w_{T}$ is the total weight of zinc in the material being tested.

\section{Results}

\subsection{Effect of the Stirring Speed}

The effects of different stirring rates of 150, 200, 250, 300, 350, and $400 \mathrm{rpm}$ on the extraction efficiency of zinc are shown in Figure 6, while the other parameters were held constant at a total ammonia concentration of $5 \mathrm{~mol} / \mathrm{L}$, a temperature of $25^{\circ} \mathrm{C}$, an ammonia/ammonium ratio of 3:1, and a liquid/solid ratio of $10 \mathrm{~mL} / \mathrm{g}$.

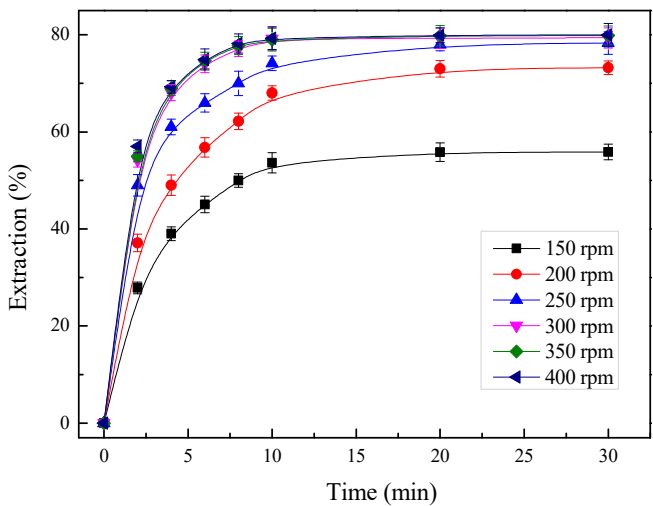

(a)

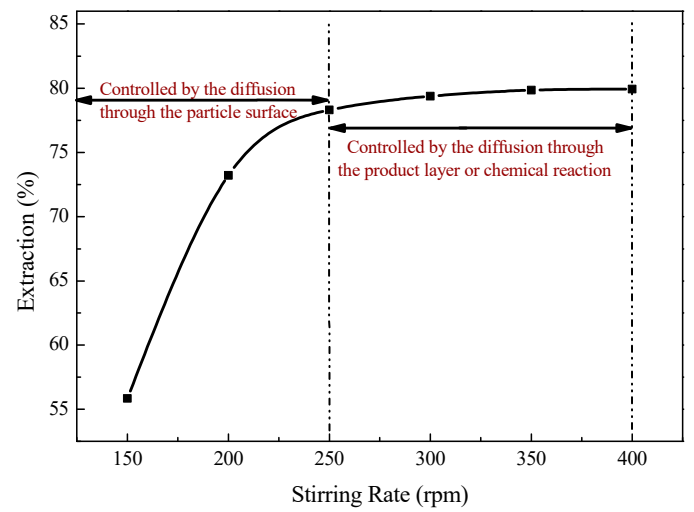

(b)

Figure 6. The effect of the stirring rate on the zinc extraction: (a) time difference; (b) 30 min of leaching.

The results indicated an increase in zinc recovery with an increase in the stirring rate, as shown in Figure 6a,b. When the stirring speed was lower than $250 \mathrm{rpm}$, a significant change happened in the zinc extraction efficiency, whereas after $250 \mathrm{rpm}$, the reaction rate only had a small increase in 30 min of leaching, as shown in Figure 6b. It can be explained that the reaction was controlled by the diffusion through the particle surface before the stirring speed reached $250 \mathrm{rpm}$, and after that, the reaction was controlled by the diffusion through the product layer or chemical reaction. Therefore, to eliminate the influence of the diffusion through the particle surface and to have a high extraction efficiency of zinc, $400 \mathrm{rpm}$ was selected as the stirring intensity for the subsequent leaching experiments.

\subsection{Effect of the Ammonia/Ammonium Ratio}

To investigate the effect of the ammonia/ammonium ratio $\left(\left[\mathrm{NH}_{3}\right] /\left[\mathrm{NH}_{4}\right]\right)$ on the zinc extraction, experiments were performed in the $\mathrm{NH}_{3}-\mathrm{NH}_{4} \mathrm{HCO}_{3}-\mathrm{H}_{2} \mathrm{O}$ system for various ammonia/ammonium ratios under the following conditions: a stirring rate of $400 \mathrm{rpm}$, a total ammonia concentration of $5 \mathrm{~mol} / \mathrm{L}$, a temperature of $25^{\circ} \mathrm{C}$, a time of $30 \mathrm{~min}$, and a liquid/solid ratio of $10 \mathrm{~mL} / \mathrm{g}$. At the same time, the $\mathrm{NH}_{3}-\mathrm{H}_{2} \mathrm{O}$ system and the $\mathrm{NH}_{4} \mathrm{HCO}_{3}-\mathrm{H}_{2} \mathrm{O}$ system were compared with the $\mathrm{NH}_{3}-\mathrm{NH}_{4} \mathrm{HCO}_{3}-\mathrm{H}_{2} \mathrm{O}$ system under the same conditions.

Figure 7 shows that the extraction efficiency of zinc first increased and then decreased with a decrease in the ammonia/ammonium ratio from 9:1 to 1:9 (as the blue bars show) in the $\mathrm{NH}_{3}-\mathrm{NH}_{4} \mathrm{HCO}_{3}-\mathrm{H}_{2} \mathrm{O}$ system. The extraction efficiency of zinc reached the maximum value after $30 \mathrm{~min}$ of leaching after the ammonia/ammonium ratio was 7:3. Meanwhile, the extraction of zinc in the $\mathrm{NH}_{3}-\mathrm{NH}_{4} \mathrm{HCO}_{3}-\mathrm{H}_{2} \mathrm{O}$ system $(78.15 \%)$ was higher than in the $\mathrm{NH}_{3}-\mathrm{H}_{2} \mathrm{O}$ system $(42 \%)$ and the $\mathrm{NH}_{4} \mathrm{HCO}_{3}-\mathrm{H}_{2} \mathrm{O}$ system $(68.38 \%)$. It indicated that the addition of ammonium bicarbonate promoted the dissolution of zinc. However, if the amount of ammonium bicarbonate added exceeds $3 / 10$ of the total amount of ammonia, there will be insufficient free ammonia, which will cause the extraction efficiency to decrease. 


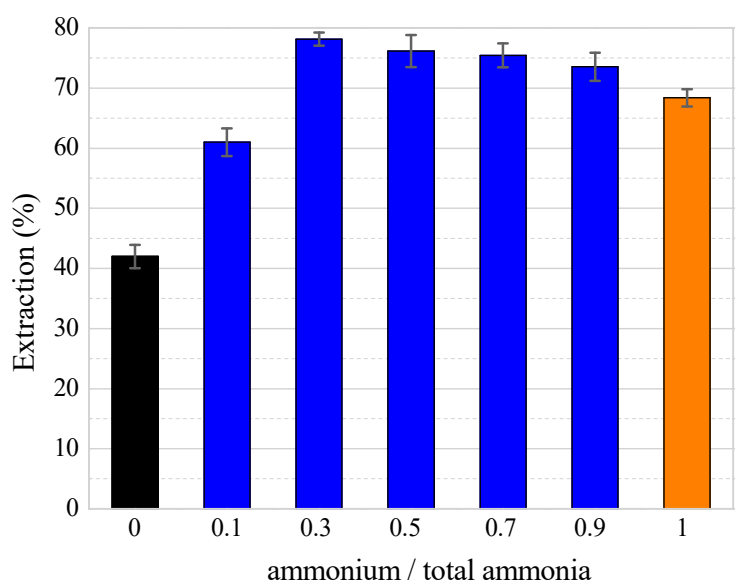

Figure 7. The effect of the ammonia/ammonium ratio on the zinc extraction. (Note: $\left[\mathrm{NH}_{4}\right],\left[\mathrm{NH}_{3}\right]$, and $\left[\mathrm{NH}_{3}\right]_{\mathrm{T}}$ represent the concentration of ammonia, the concentration of ammonium, and the total ammonia concentrations of ammonia and ammonium, respectively.)

\subsection{Effect of the Temperature}

Taking into account the strong volatile characteristics of the leaching agent at high temperatures, the effects of leaching temperature were assessed in the range from 5 to $70{ }^{\circ} \mathrm{C}$, while the other parameters were held constant at a total ammonia concentration of $5 \mathrm{~mol} / \mathrm{L}$, a liquid/solid ratio of $10 \mathrm{~mL} / \mathrm{g}$, an ammonia/ammonium ratio of 7:3, and a stirring rate of $400 \mathrm{rpm}$. Figure 8 shows that the leaching temperature had a significant effect on the zinc extraction. When the temperature increased from 5 to $35^{\circ} \mathrm{C}$, the extraction efficiency increased with the increase of temperature, but when the temperature continued to rise, the opposite phenomenon occurred, as shown in Figure 8a. This can be explained as ammonium bicarbonate began to decompose above $35^{\circ} \mathrm{C}$ and then violently decomposed above $60^{\circ} \mathrm{C}$. Therefore, to avoid the interference of other factors when studying the leaching kinetics, the test temperature was controlled below $35^{\circ} \mathrm{C}$.

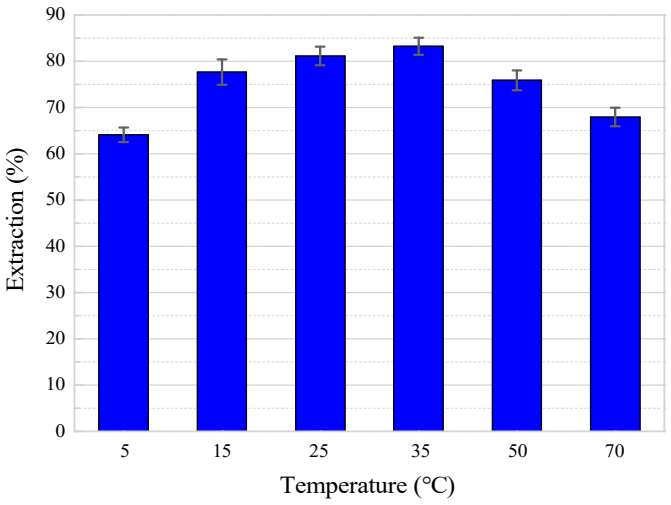

(a)

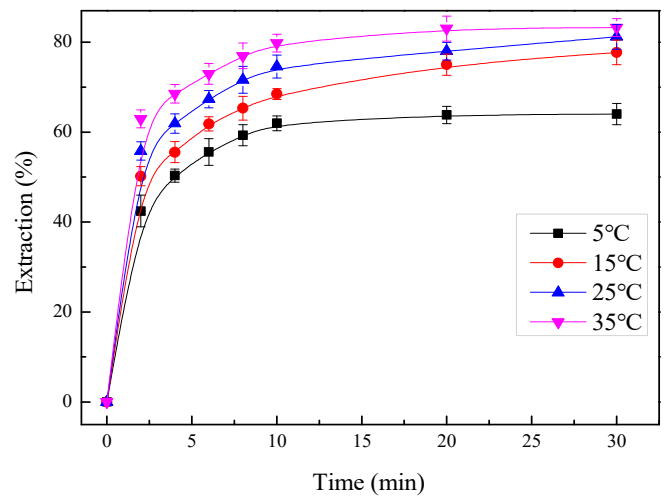

(b)

Figure 8. The effect of temperature on the zinc extraction: (a) 30 min of leaching time; (b) time difference.

The forms of shrinking core models that account for diffusion through the product layer and the chemical reaction were tested with the experimental data. Figure 9 presents the fit of the model equation in Table 2 with the experimental data. It can be noted that the experimental data matched Equation (3) better, which was proved by the high $R^{2}$ value (Figure $9 \mathrm{~d}$ ). Hence, the process was controlled by the product layer diffusion, which belongs to the shrinking core model of constant-size particles. 


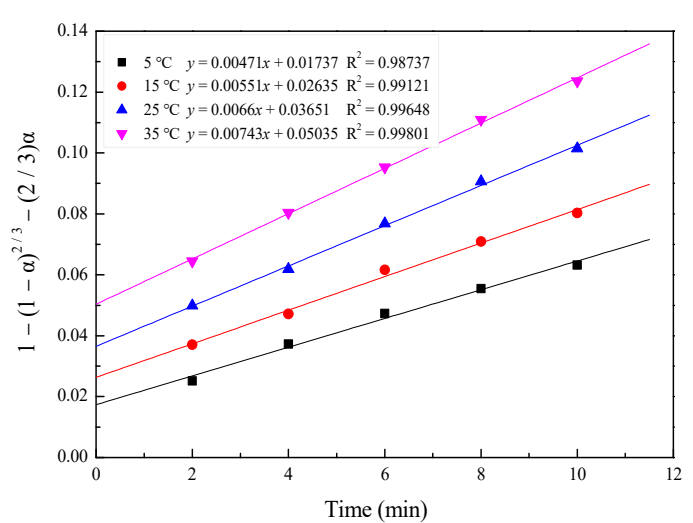

(a)

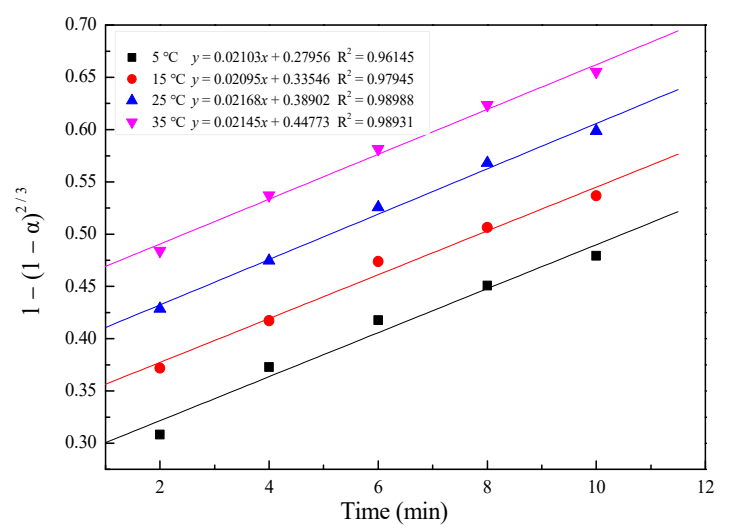

(c)

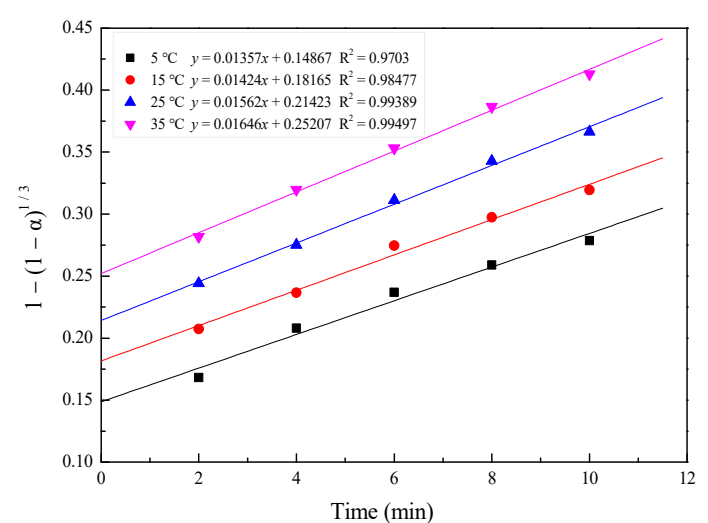

(b)

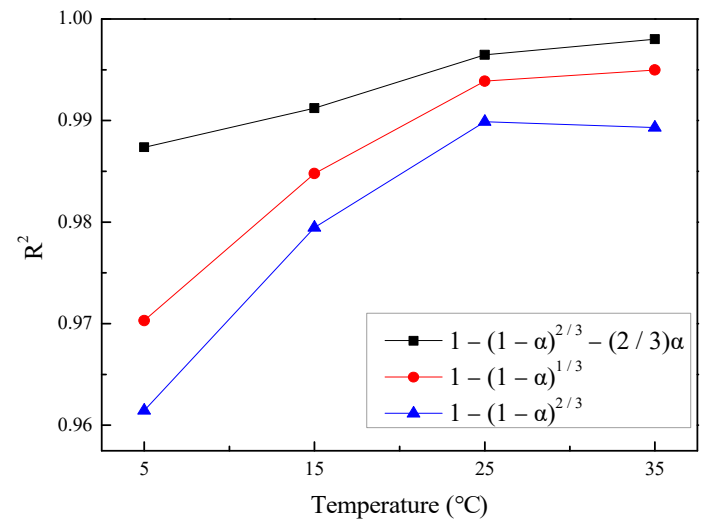

(d)

Figure 9. Plots of $(\mathbf{a}) 1-(1-\alpha)^{2 / 3}-(2 / 3) \alpha,(\mathbf{b}) 1-(1-\alpha)^{1 / 3}$, and (c) $1-(1-\alpha)^{2 / 3}$ versus time for various temperatures and (d) $R^{2}$ versus temperature for various equations.

The Arrhenius curve of $\ln k_{d}$ versus 1000/T for the model is shown in Figure 10; it presented a good linear relationship. The activation energy was calculated to be $11.04 \mathrm{KJ} \cdot \mathrm{mol}^{-1}$, which further evidenced the leaching process being controlled by the diffusion of ions through the product layer [24,25].

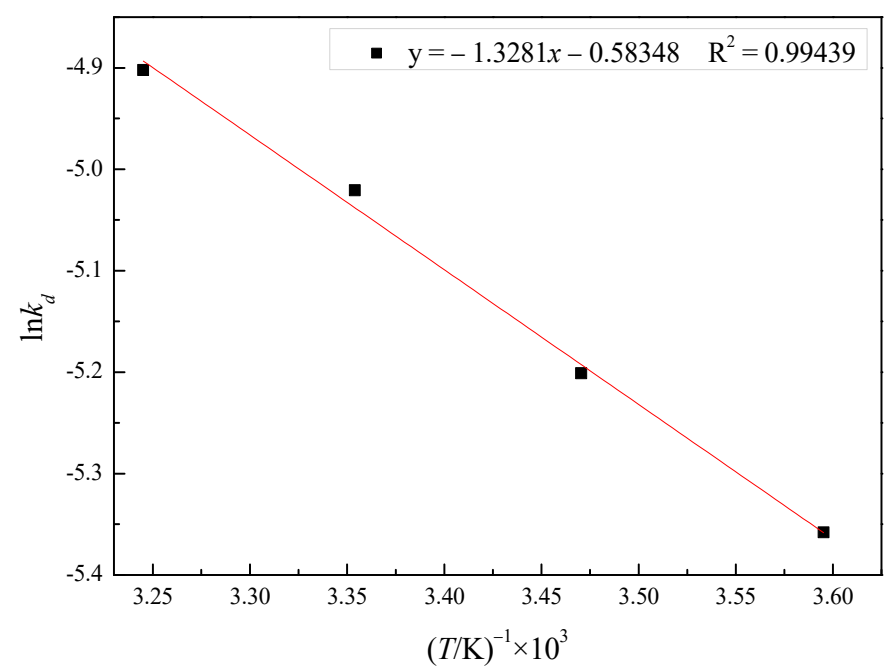

Figure 10. Arrhenius plot of the reaction rate against the reciprocal of temperature (278 to $308 \mathrm{~K})$. 


\subsection{Effect of the Total Ammonia Concentration}

To investigate the effect of the total ammonia concentration on the extraction of zinc, the total ammonia concentration was varied from 1 to $5 \mathrm{~mol} / \mathrm{L}$, with other parameters being held at a temperature of $35^{\circ} \mathrm{C}$, a liquid/solid ratio of $10 \mathrm{~mL} / \mathrm{g}$, an ammonia/ammonium ratio of 7:3, and a stirring rate of $400 \mathrm{rpm}$. Figure 11 shows that in the first $10 \mathrm{~min}$, and as time passed, the increase rate of the zinc extraction increased significantly with the increase in total ammonia concentration. The extraction efficiencies of zinc increased from 30.03 to $81 \%$ after $30 \mathrm{~min}$ of leaching with the increase in the total ammonia concentration from 1 to $5 \mathrm{~mol} / \mathrm{L}$. The results indicated that a higher total ammonia concentration leads to a greater extraction of zinc. The maximum recovery in excess of $81 \%$ was achieved at the highest total ammonia concentration of $5 \mathrm{~mol} / \mathrm{L}$. However, at a total ammonia concentration higher than $4 \mathrm{~mol} / \mathrm{L}$, the increase in zinc recovery was not significant. The decrease in the rate of extraction with time could be attributed to the reduction in total ammonia concentration, which was due to the consumption in the reaction. Therefore, for economic considerations, the appropriate total ammonia concentration should be $4 \mathrm{~mol} / \mathrm{L}$.

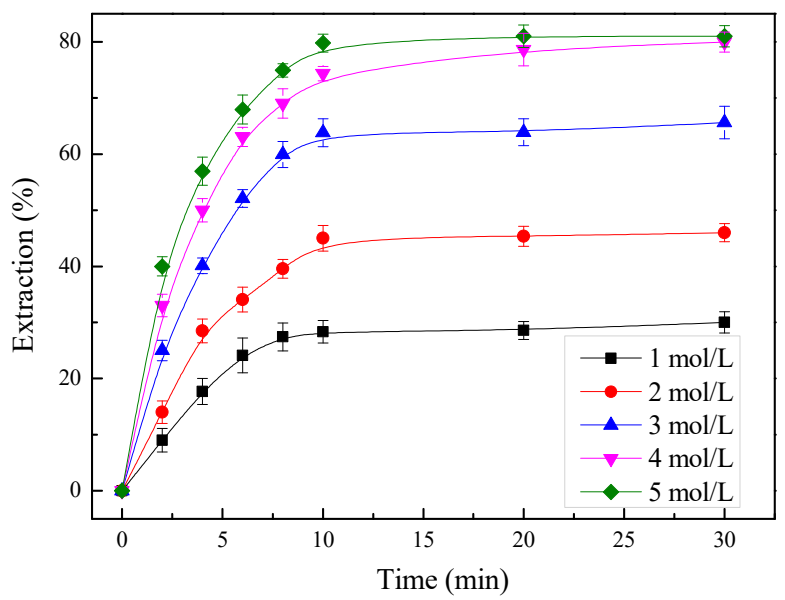

Figure 11. Effect of the total ammonia concentration on the zinc extraction at a temperature of $35^{\circ} \mathrm{C}$.

To estimate the order of the reaction with respect to the total ammonia concentration, the plots of $1-(1-\alpha)^{2 / 3}-(2 / 3) \alpha$ vs. $t$ and $\ln k_{d}$ vs. $\ln \left[\mathrm{NH}_{3}\right]_{\mathrm{T}}$ were utilized, as shown in Figure 12. An order of the reaction with respect to the total ammonia concentration of 1.53 was estimated with the correlation coefficient $\left(R^{2}\right)$ being 0.98249 .

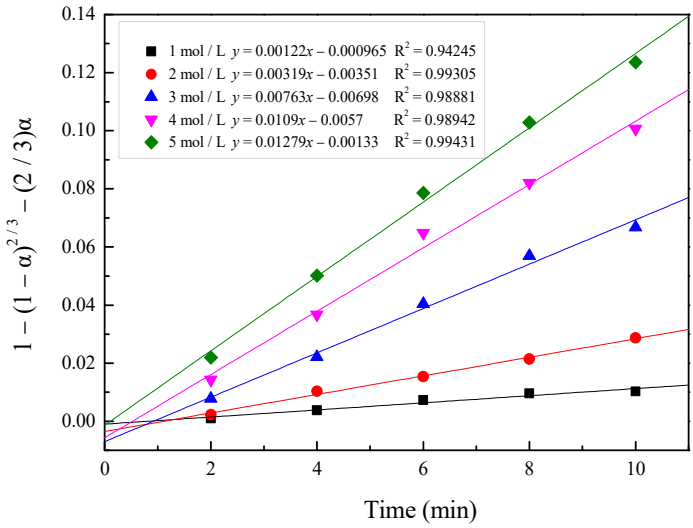

(a)

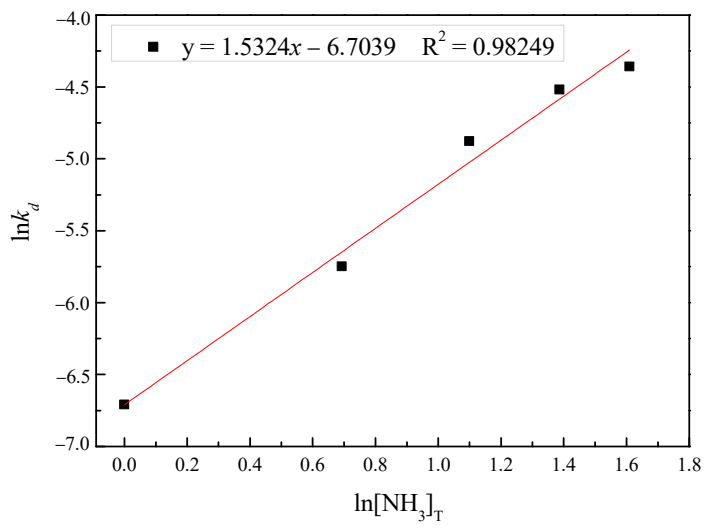

(b)

Figure 12. (a) Plot of $1-(1-\alpha)^{2 / 3}-(2 / 3) \alpha$ versus time for various total ammonia concentrations; (b) plot for the determination of reaction order with respect to $\ln \left[\mathrm{NH}_{3}\right]_{\mathrm{T}}$. 


\subsection{Effect of the Liquid/Solid Ratio}

The changes in the zinc extraction with the liquid/solid ratio were investigated, with the other parameters held at a temperature of $35^{\circ} \mathrm{C}$, an ammonia/ammonium ratio of $7: 3$, a stirring rate of $400 \mathrm{rpm}$, and a total ammonia concentration of $4 \mathrm{~mol} / \mathrm{L}$. The results, shown in Figure 13, indicated that the increase in the liquid/solid ratio enhanced zinc recovery effectively until a liquid/solid ratio of $7 \mathrm{~mL} / \mathrm{g}$. The leaching dose consumed per unit mass of zinc was fixed, and a low liquid/solid ratio will result in a higher viscosity of the leaching solution, which will limit the volume of the leaching agent. The leaching of zinc was affected because the diffusion rate of the solvent through the boundary layer was low.

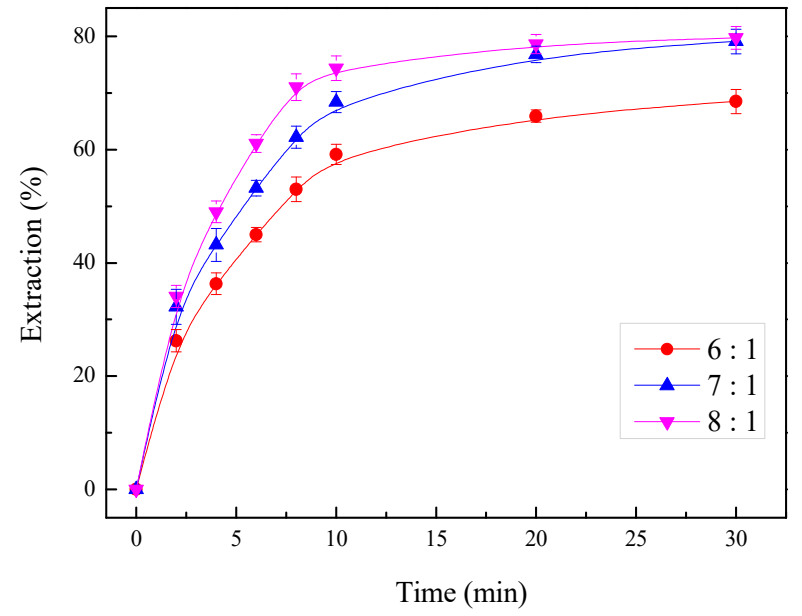

Figure 13. Effect of the liquid/solid ratio on the zinc extraction.

To estimate the order of reaction with respect to the liquid/solid ratio, the plots of $1-(1-\alpha)^{2 / 3}-(2 / 3) \alpha$ vs. $t$ and $\ln k_{d}$ vs. $\ln (l / s)$ were utilized, as shown in Figure 14. An order of the reaction with respect to the liquid/solid ratio of 2.26 was estimated with the correlation coefficient $\left(R^{2}\right)$ being 0.9971 .

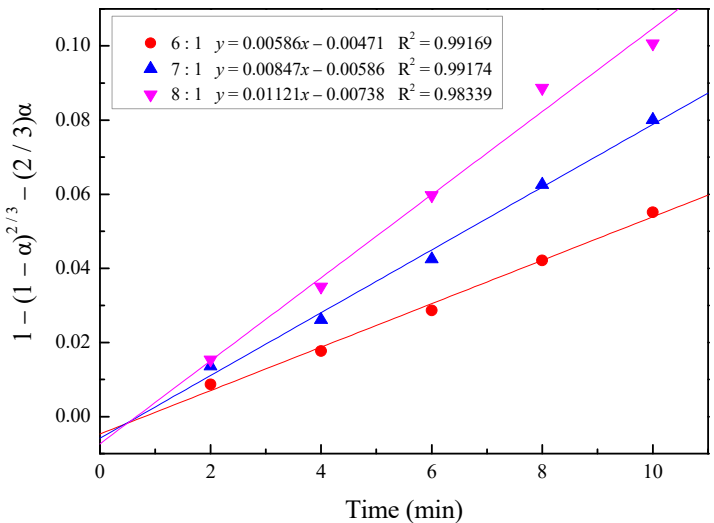

(a)

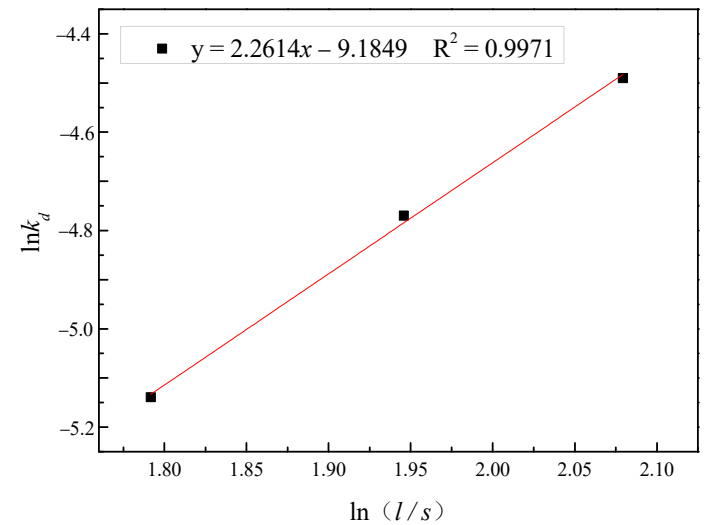

(b)

Figure 14. (a) Plot of $1-(1-\alpha)^{2 / 3}-(2 / 3) \alpha$ versus time for various liquid/solid ratios; (b) plot of $\ln k_{d}$ versus $\ln (l / s)$.

According to the analysis above, a kinetic equation for the diffusion through the product-layer-controlled process using the shrinking core model of constant-size particles was developed and met the following equation:

$$
1-\left(\frac{2}{3}\right) \alpha-(1-\alpha)^{2 / 3}=k_{d} t=k_{0}\left[\mathrm{NH}_{3}\right]_{\mathrm{T}}^{1.53} \times(l / s)^{2.26} \exp \left(\frac{-11040}{\mathrm{RT}}\right) t
$$


The effects of the stirring rate, the leaching time, the temperature, the total ammonia concentration, the ammonia/ammonium ratio, and the liquid/solid ratio on the leaching kinetics of zinc were assessed, and the kinetics were modeled using the shrinking core model of constant-size particles. The results showed that nearly $80 \%$ of zinc recovery was obtained at the optimum leaching conditions of a stirring rate of $400 \mathrm{rpm}$, a leaching temperature of $35^{\circ} \mathrm{C}$, and an ammonia/ammonium ratio of 7:3 for 30 min with $4 \mathrm{~mol} / \mathrm{L}$ total ammonia concentration using a liquid/solid ratio of $7 \mathrm{~mL} / \mathrm{g}$.

The XRD pattern of the leaching residue obtained under the optimal conditions is shown in Figure 15. Compared with the XRD pattern of the initial material sample, it was found that the diffraction peaks of $\mathrm{ZnO}$ and $\mathrm{PbCl}_{2}$ disappeared and the diffraction peaks of $\mathrm{PbCO}_{3}$ appeared. This can be explained by the complete dissolution of $\mathrm{ZnO}$ in the leaching solution. Additionally, the solubility product of $\mathrm{PbCO}_{3}$ was smaller than $\mathrm{PbCl}_{2}$, so the lead was transferred from $\mathrm{PbCl}_{2}$ to $\mathrm{PbCO}_{3}$. Meanwhile, because $\mathrm{ZnFe}_{2} \mathrm{O}_{4}$ is insoluble in the leaching agent, the intensity of the $\mathrm{ZnFe}_{2} \mathrm{O}_{4}$ peaks were significantly enhanced, which is why the extraction efficiency of zinc can only be close to $80 \%$.

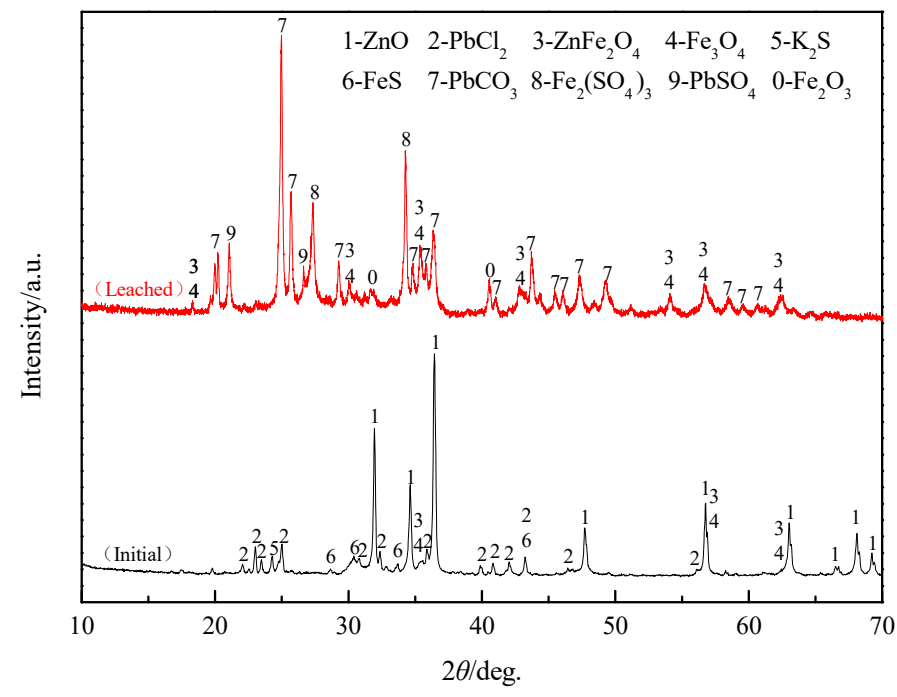

Figure 15. XRD pattern of the initial residue and the leached residue.

The chemical composition of the leachate obtained under the optimal conditions using inductive coupled plasma emission spectrometer (ICP) detection is shown in Table 3. It can be seen that, in addition to zinc, cadmium, copper, and lead have also entered the solution because they will also react with ammonia to complex ions. Because of the presence of carbonate in the solution, most of the lead will remain in the slag in the form of $\mathrm{PbCO}_{3}$.

Table 3. The chemical composition of the leachate.

\begin{tabular}{ccccc}
\hline Element & $\mathbf{Z n}$ & $\mathbf{C d}$ & $\mathbf{P b}$ & $\mathbf{C u}$ \\
\hline $\begin{array}{c}\text { Concentration } \\
(\mathrm{mg} / \mathrm{L})\end{array}$ & 59674 & 442.5 & 236 & 25.6 \\
\hline
\end{tabular}

\subsection{SEM-EDS Analysis of the Sample}

Scanning electron microscopy (SEM) with energy-dispersive X-ray spectroscopy (EDS) measurements (SEM-EDS) of SZO and leached residue sample particles were performed to obtain additional information on the structure, morphology, and chemical composition of the residue, as shown in Figures 16-18. 


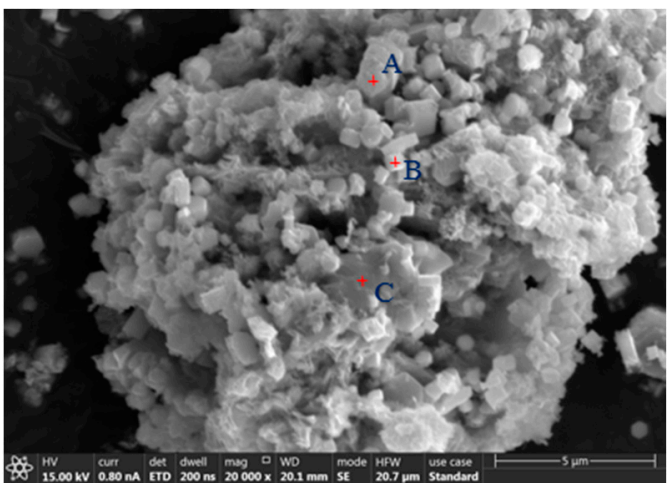

(a)

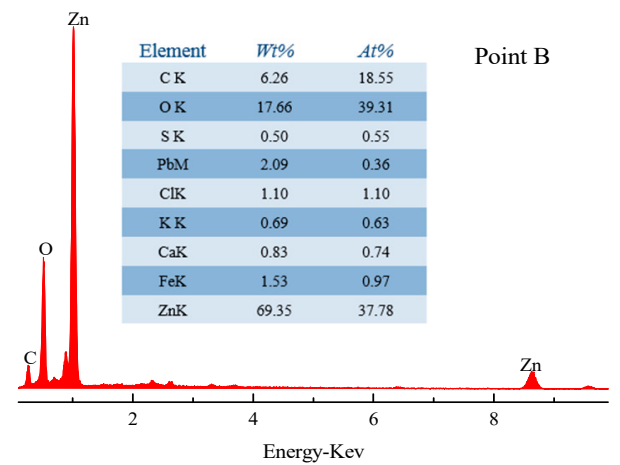

(c)

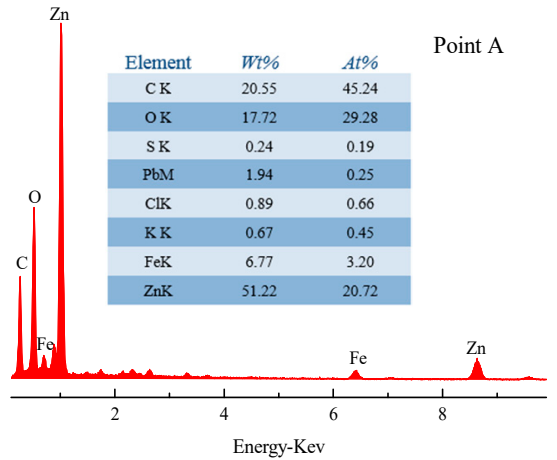

(b)

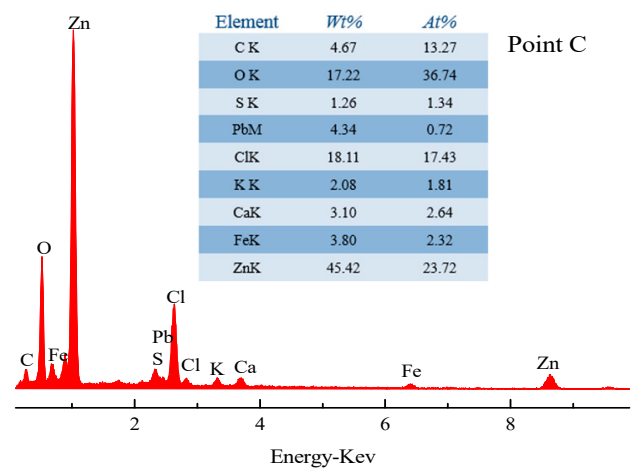

(d)

Figure 16. (a) SEM pattern of SZO; (b) EDS pattern of point A; (c) EDS pattern of point B; (d) EDS pattern of point C.

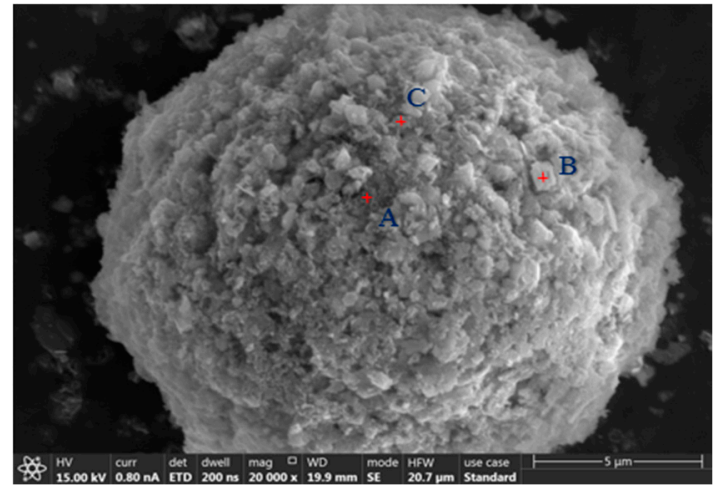

(a)

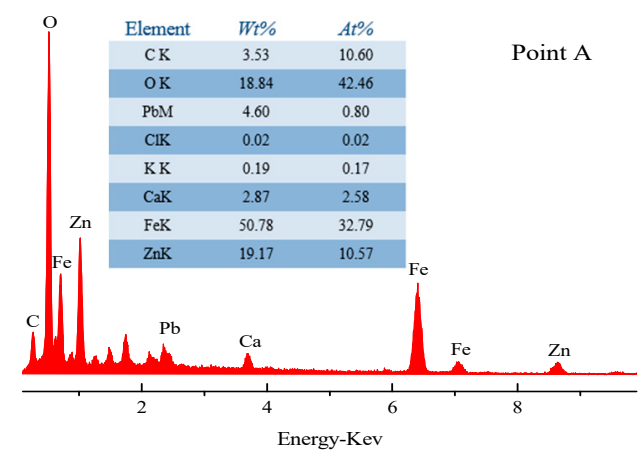

(b)

Figure 17. Cont. 


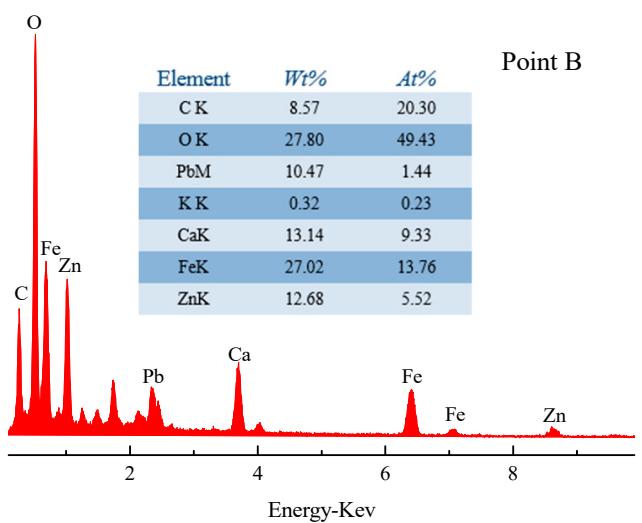

(c)

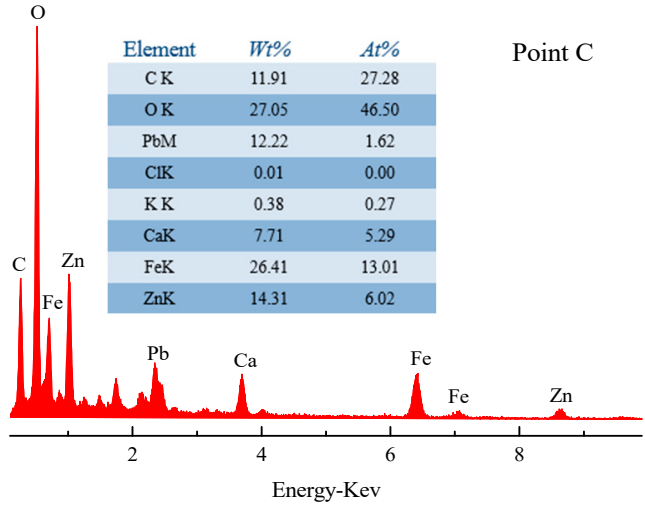

(d)

Figure 17. (a) SEM pattern of the leached residue; (b) EDS pattern of point A; (c) EDS pattern of point B; (d) EDS pattern of point C.

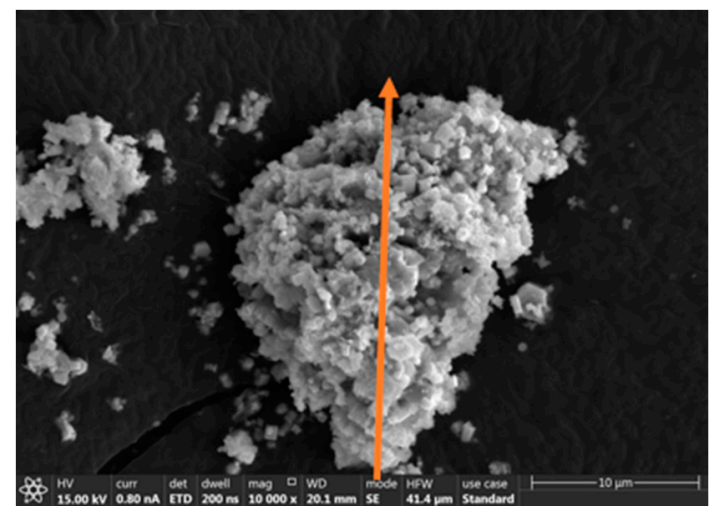

(a)

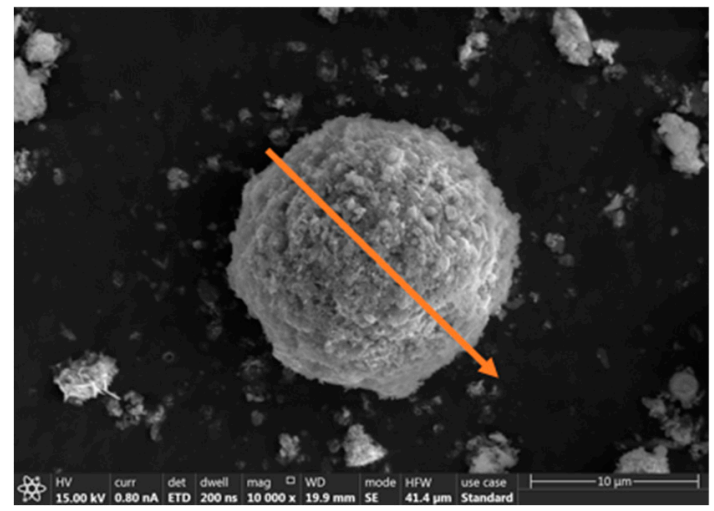

(c)

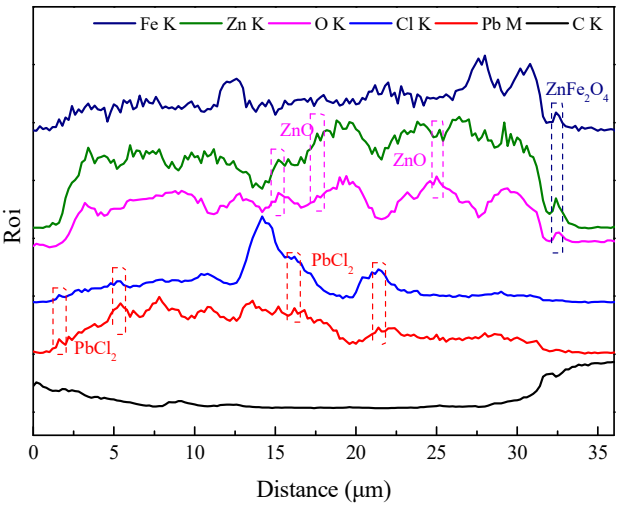

(b)

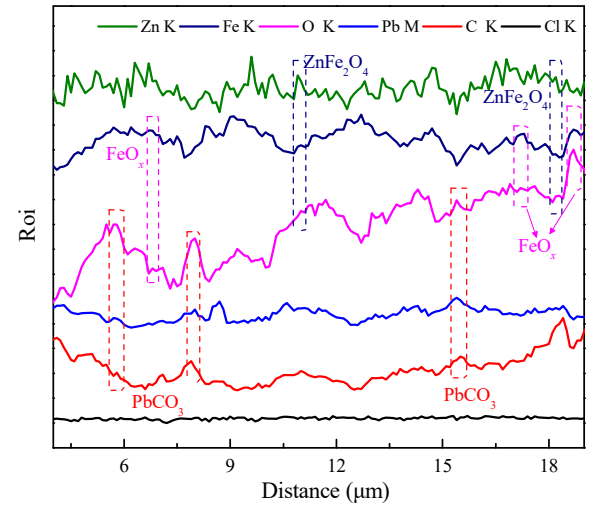

(d)

Figure 18. Line-scanning patterns of $(\mathbf{a}, \mathbf{b}) \mathrm{SZO}$ and $(\mathbf{c}, \mathbf{d})$ the leached residue.

It can be noticed that the surface of the SZO sample was rough and had obvious particle adhesion, as shown in Figure 16. The sample mainly existed in three typical areas: bright large granular areas (point A), bright small granular areas (point B), and gray areas (point C). EDS analysis showed that zinc was more distributed in all areas; iron was mainly distributed in bright large granular area (point $\mathrm{A}$ ); and $\mathrm{Pb}, \mathrm{S}, \mathrm{Cl}$, and $\mathrm{K}$ were primarily found in gray areas (point $C$ ). The difference was that the surface of the leached residue sample was relatively complete in Figure 17. The sample mainly existed in two typical structures: amorphous (point A) and granular (points B and C) structures. EDS analysis 
showed that $\mathrm{Zn}$ and Fe were mainly distributed in the amorphous structure (point $\mathrm{A}$ ), and $\mathrm{Pb}, \mathrm{Ca}$, and $\mathrm{C}$ were primarily found in the granular structure (points $\mathrm{B}$ and $\mathrm{C}$ ).

From the line-scanning patterns in Figure 18, it can be seen that zinc existed in the form of $\mathrm{ZnO}$ and $\mathrm{ZnFe}_{2} \mathrm{O}_{4}$ and lead existed in the form of $\mathrm{PbCl}_{2}$ in SZO. Meanwhile, the line-scanning pattern of leached residue made it clear that $\mathrm{ZnFe}_{2} \mathrm{O}_{4}$ was not leaching in the $\mathrm{NH}_{3}-\mathrm{NH}_{4} \mathrm{HCO}_{3}-\mathrm{H}_{2} \mathrm{O}$ system and that lead was transferred from $\mathrm{PbCl}_{2}$ to $\mathrm{PbCO}_{3}$ in the leaching process.

\section{Conclusions}

(1) The thermodynamic analysis of the Pourbaix diagram and the chemical dissolution equilibrium of the $\mathrm{SZO}$ leaching experiment in the $\mathrm{NH}_{3}-\mathrm{NH}_{4} \mathrm{HCO}_{3}-\mathrm{H}_{2} \mathrm{O}$ system indicated that it is feasible to extract zinc with a mixture of ammonia and ammonium bicarbonate as the leaching agent. Additionally, $\left(\mathrm{Zn}\left(\mathrm{NH}_{3}\right)_{4}\right)^{2+}$ was determined as the dominant component in the solution under the experimental conditions.

(2) The process of leaching significantly improved zinc recovery from SZO in the $\mathrm{NH}_{3}-\mathrm{NH}_{4} \mathrm{HCO}_{3}-\mathrm{H}_{2} \mathrm{O}$ system. The effects of the stirring rate, the leaching time, the temperature, the total ammonia concentration, the ammonia/ammonium ratio, and the liquid/solid ratio on the leaching kinetics of zinc were assessed. The results indicated that nearly $80 \%$ of zinc recovery was obtained at the optimum leaching conditions of a stirring rate of $400 \mathrm{rpm}$, an ammonia/ammonium ratio of 7:3, a total ammonia concentration of $4 \mathrm{~mol} / \mathrm{L}$, and a liquid/solid ratio of $7 \mathrm{~mL} / \mathrm{g}$ for $30 \mathrm{~min}$ at $35^{\circ} \mathrm{C}$. The leaching process of $\mathrm{SZO}$ in the $\mathrm{NH}_{3}-\mathrm{NH}_{4} \mathrm{HCO}_{3}-\mathrm{H}_{2} \mathrm{O}$ system was controlled by the diffusion through the product layer, which belongs to the shrinking core model of constant-size particles.

Author Contributions: Conceptualization, L.Z.; methodology, H.L.; software, L.W.; validation, H.Y.; investigation, J.L. (Jinglong Liang); resources, J.L. (Jinrui Liu). All authors have read and agreed to the published version of the manuscript.

Funding: This research was funded by the National Natural Science Foundation of China, grant number 51874141, the Basic Scientific Research Business Expenses Fund of the Provincial Colleges and Universities of Hebei, grant number JXC2019009, and the Funded by Science and Technology Project of Hebei Education Department, grant number ZD2021331.

Data Availability Statement: Not applicable.

Conflicts of Interest: The authors declare no conflict of interest.

\section{References}

1. Hu, H.; Deng, Q.; Li, C.; Xie, Y.; Dong, Z.; Zhang, W. The recovery of Zn and Pb and the manufacture of lightweight bricks from zinc smelting slag and clay. J. Hazard. Mater. 2014, 271, 220-227. [CrossRef]

2. Jaafar, I.; Griffiths, A.J.; Hopkins, A.C.; Steer, J.M.; Griffiths, M.H.; Sapsford, D.J. An evaluation of chlorination for the removal of zinc from steelmaking dusts. Miner. Eng. 2011, 24, 1028-1030. [CrossRef]

3. Trinkel, V.; Mallow, O.; Thaler, C.; Schenk, J.; Rechberger, H.; Fellner, J. Behavior of Chromium, Nickel, Lead, Zinc, Cadmium, and Mercury in the Blast Furnace-A Critical Review of Literature Data and Plant Investigations. Ind. Eng. Chem. Res. 2015, 54, 11759-11771. [CrossRef]

4. Trinkel, V.; Mallow, O.; Aschenbrenner, P.; Rechberger, H.; Fellner, J. Characterization of Blast Furnace Sludge with Respect to Heavy Metal Distribution. Ind. Eng. Chem. Res. 2016, 55, 5590-5597. [CrossRef]

5. Kukurugya, F.; Vindt, T.; Havlík, T. Behavior of zinc, iron and calcium from electric arc furnace (EAF) dust in hydrometallurgical processing in sulfuric acid solutions: Thermodynamic and kinetic aspects. Hydrometallurgy 2015, 154, 20-32. [CrossRef]

6. Frenay, J. Leaching of oxidized zinc ores in various media. Hydrometallurgy 1985, 15, 243-253. [CrossRef]

7. Tang, J.; Steenari, B.M. Solvent extraction separation of copper and zinc from MSWI fly ash leachates. Waste Manag. 2015, 44, 147-154. [CrossRef] [PubMed]

8. Langová, Š.; Matýsek, D. Zinc recovery from steel-making wastes by acid pressure leaching and hematite precipitation. Hydrometallurgy 2010, 101, 171-173. [CrossRef]

9. Orhan, G.K. Leaching and cementation of heavy metals from electric arc furnace dust in alkaline medium. Hydrometallurgy 2005, 78, 236-245. [CrossRef]

10. Dutra, A.J.B.; Paiva, P.R.P.; Tavares, L.M. Alkaline leaching of zinc from electric arc furnace steel dust. Miner. Eng. 2006, 19, 478-485. [CrossRef] 
11. Ma, A.; Zhang, L.; Peng, J.; Zheng, X.; Li, S.; Yang, K.; Chen, W. Extraction of zinc from blast furnace dust in ammonia leaching system. Green Process. Synth. 2016, 5, 23-30. [CrossRef]

12. Zhang, D.; Zhang, X.; Yang, T.; Rao, S.; Hu, W.; Liu, W.; Chen, L. Selective leaching of zinc from blast furnace dust with mono-ligand and mixed-ligand complex leaching systems. Hydrometallurgy 2017, 169, 219-228. [CrossRef]

13. Gargul, K.; Boryczko, B. Removal of zinc from dusts and sludges from basic oxygen furnaces in the process of ammoniacal leaching. Arch. Civ. Mech. Eng. 2015, 15, 179-187. [CrossRef]

14. Saleh, H.; Hassan, K. Extraction of zinc from blast-furnace dust using ammonium sulfate. J. Chem. Technol. Biot. 2004, 79, 397-402. [CrossRef]

15. Shin, S.; Kang, J.; Yang, D.; Sohn, J.S.; Kim, T. Selective Leaching of Zinc from Spent Zinc-Carbon Battery with Ammoniacal Ammonium Carbonate. Mater. Trans. 2008, 49, 2124-2128. [CrossRef]

16. Xu, H.; Wei, C.; Li, C.; Fan, G.; Deng, Z.; Zhou, X.; Qiu, S. Leaching of a complex sulfidic, silicate-containing zinc ore in sulfuric acid solution under oxygen pressure. Sep. Purif. Technol. 2012, 85, 206-212. [CrossRef]

17. Cantarino, M.V.; Filho, C.D.C.; Mansur, M.B. Selective removal of zinc from basic oxygen furnace sludges. Hydrometallurgy 2012, 111, 124-128. [CrossRef]

18. Liu, Z.X.; Yin, Z.L.; Hu, H.P.; Chen, Q.Y. Leaching kinetics of low-grade copper ore containing calcium-magnesium carbonate in ammonia-ammonium sulfate solution with persulfate. T. Nonferr. Metal. Soc. 2012, 22, 2822-2830. [CrossRef]

19. Liu, Z.X.; Yin, Z.L.; Hu, H.P.; Chen, Q.Y. Dissolution kinetics of malachite in ammonia/ammonium sulphate solution. J. Cen. South Univ. T. 2012, 19, 903-910. [CrossRef]

20. Rao, S.; Yang, T.; Zhang, D.; Liu, W.; Chen, L.; Hao, Z.; Xiao, Q.; Wen, J. Leaching of low grade zinc oxide ores in $\mathrm{NH}_{4} \mathrm{Cl}_{-} \mathrm{NH}_{3}$ solutions with nitrilotriacetic acid as complexing agents. Hydrometallurgy 2015, 158, 101-106. [CrossRef]

21. Ma, A.; Zheng, X.; Li, S.; Wang, Y.; Zhu, S. Zinc recovery from metallurgical slag and dust by coordination leaching in $\mathrm{NH}_{3}-$ $\mathrm{CH}_{3} \mathrm{COONH}_{4}-\mathrm{H}_{2} \mathrm{O}$ system. R. Soc. Open Sci. 2018, 5, 180660. [CrossRef] [PubMed]

22. Liddell, K.C. Shrinking core models in hydrometallurgy: What students are not being told about the pseudo-steady approximation. Hydrometallurgy 2005, 79, 62-68. [CrossRef]

23. Teir, S.; Revitzer, H.; Eloneva, S.; Fogelholm, C.J.; Zevenhoven, R. Dissolution of natural serpentinite in mineral and organic acids. Int. J. Miner. Process. 2007, 83, 36-46. [CrossRef]

24. Peng, N.; Peng, B.; Liu, H.; Lin, D.H.; Xue, K. Leaching kinetics modelling of reductively roasted zinc calcine. Can. Metall. Quart. 2017, 56, 301-307. [CrossRef]

25. Yang, S.H.; Li, H.; Sun, Y.W.; Chen, Y.M.; Tang, C.B.; He, J. Leaching kinetics of zinc silicate in ammonium chloride solution. T. Nonferr. Metal Soc. 2016, 26, 1688-1695. [CrossRef] 